science at Washington University. Many a student who entered his classroom hoping to fulfill a required elective course ended up joining the ever-widening circle of comparativists.

An outstanding characteristic of Victor LeVine was a spirit of egalitarianism, which he nurtured in and outside of the classroom. Whether chairing a dissertation committee, discussing papers in a panel, or leading a workshop on conflict resolution, he was inclusive and encouraging of women, minorities, and the non-political science majors who flocked into his classes. He practiced what he preached on respecting the right of every individual to a life of dignity and did not tolerate bigotry in any form or shape. He maintained his dignity as a free thinker and confronted parochialism using his intellect to win the battle with dignity against forces of McCarthyism and racism. Not forgetting his early years as a refugee from Nazi Germany, Le Vine also advocated for human rights and the equitable treatment of refugees fleeing tyrant regimes. $\mathrm{He}$ spent many hours gathering data on the human rights abuses suffered by opponents of regimes in francophone Africa and provided well-documented testimonials for asylum applicants seeking freedom.

Le Vine's abiding interest in peace and conflict resolution was born out of his understanding of its antithesis-war and the scourge of violence that haunted his generation. His analyses of nation building, war, and peace were always pragmatic and balanced. He did not shy away from volatile subjects such as the one- or twostate solution in Israel/Palestine; U.S. intervention in Iraq; terrorism and suicide bombers; electoral fraud in Africa, the Middle East, and Russia; and piracy in the Indian Ocean. His op-ed pieces in the St. Louis Post-Dispatch and his insistence on academic integrity in comparative analysis of foreign policymaking in the twentyfirst century will be sorely missed by his readers. A career spanning a half-century at Washington University in St. Louis (1961-2003; 2003-2010) ended at dawn on May 7, 2010, but Victor T. Le Vine left behind him a legacy of academic excellence, collegiality, and a compendium of work that bridged the twentieth and twenty-first centuries. He is survived by his wife, Nathalie; two children; four grandchildren; and two great-grandchildren.

Ruth Iyob University of Missouri-St. Louis
EUGENE F. MILLER

It is with great sadness that we report the passing of our longtime friend and colleague, Dr. Eugene F. Miller, professor emeritus of political science at the University of Georgia, who taught in the department of political science with great distinction from 1967 until his retirement in 2003. He died on May 30, 2010, following a two-year battle with multiple myeloma.

He was born in Atlanta on October 1, 1935, and received an undergraduate degree from Emory University in 1957 . While at Emory, he received a Danforth Graduate Fellowship, which supported his Ph.D. studies at the University of Chicago. At Chicago, he was affiliated with the Committee on Social Thought and wrote his dissertation under the direction of the Nobel laureate Friedrich A. Hayek. He also studied with Leo Strauss, who deeply influenced his thinking and research. He completed his doctorate in 1965. Gene taught at Davidson College (1962-63) and Furman University (1963-67) before moving to the University of Georgia.

Gene was an accomplished scholar who brought a probing and deep intelligence to his research, whether it involved the exploration of fundamental issues in the philosophy of social science in an article that was the focus of a symposium in the American Political Science Review, or a historical investigation leading to a learned and definitive edition of major writings by David Hume. His love of scholarship held to the end: very shortly before his death he completed a book on Hayek's The Constitution of Liberty, which will soon be published by the Institute of Economic Affairs, a British free-market think tank. In a sense, his academic life came full circle.

An extraordinarily gifted, respected, and award-winning teacher, Gene was able to bring out the best efforts of his students in part because he insisted on excellence, in part because his caring and attentive manner made disappointing the instructor unthinkable in his classes.

As the department's graduate coordinator, Gene revolutionized the program. This required a tenacious political will and calm persistence, but also long hours: colleagues could not help but notice him working in his office, no matter how late they themselves left the political science building. More broadly, for decades, Gene was active in the programs of the Liberty Fund, helping to organize stellar conferences around the country.
Finally, it would be difficult to overstate Gene's warmth, generosity, good humor, and, in his last years, grace in the face of death. With all his intelligence and insight, he never felt the need to convince others of his abilities. He was a key mentor to one of us, despite profound philosophical differences. It never occurred to him that these differences were relevant to how he should treat a colleague or fellow human being. We have written this memorial, then, not simply to note Gene's professional accomplishments, but as an expression of gratitude.

Robert Grafstein
University of Georgia
John Maltese
University of Georgia

\section{DANIEL HUBBARD POLLITT}

Daniel Hubbard Pollitt, Graham Kenan Professor of Law emeritus of the UNCChapel Hill School of Law died March 5, surrounded by the love of his family. Dan loved his family, the Constitution and the Bill of Rights, Holden Beach, and Tar Heel basketball.

Pollitt was born July 6, 1921, in Washington, DC, to Mima Riddiford and Basil Hubbard Pollitt. He graduated from Wesleyan University in Connecticut early to join the Marines. He fought in the Pacific as a Second Lieutenant in World War II, receiving several Purple Hearts. After the war, he attended Cornell Law School, where he served on the Law Review. He clerked for Judge Henry Edgerton of the U.S. Court of Appeals for the District of Columbia. Later, he joined the law firm of Joseph Rauh, Jr., beginning a lifetime of defending civil rights, civil liberties, and fighting injustices in local, state, and national arenas.

In 1951, he married Jean Ann Rutledge (1925-2006), daughter of Supreme Court Justice Wiley B. Rutledge and Annabel Person Rutledge. He and his wife of 55 years had three children, Daniel, Phoebe, and Susan.

In 1957, he moved to Chapel Hill, where he joined the faculty at the law school. A constitutional and labor law professor, he was active in numerous organizations including the NAACP, ACLU, AAUP, Southerners for Economic Justice, and RAFI. He was president of the faculty for four years.

Some of the honors and awards he received include the Order of the Long-Leaf 